\title{
Distinct linear hydrocarbon profiles and chemical strategy of facultative parasitism among Mischocyttarus wasps
}

\author{
A.C. Ferreira ${ }^{1,2}$, C.A.L. Cardoso ${ }^{1,2}$, E.F. Neves $^{3}$, Y.R. Súarez ${ }^{1,3}$ and \\ W.F. Antonialli-Junior ${ }^{1,3}$ \\ ${ }^{1}$ Programa de Pós-Graduação em Recursos Naturais, \\ Universidade Estadual de Mato Grosso do Sul, Dourados, MS, Brasil \\ ${ }^{2}$ Laboratório de Cromatografia, Centro de Pesquisa em Biodiversidade, \\ Universidade Estadual de Mato Grosso do Sul, Dourados, MS, Brasil \\ ${ }^{3}$ Laboratório de Ecologia, Centro Integrado de Análise e Monitoramento Ambiental, \\ Universidade Estadual de Mato Grosso do Sul, Dourados, MS, Brasil \\ Corresponding author: W.F. Antonialli-Junior \\ E-mail: williamantonialli@yahoo.com.br
}

Genet. Mol. Res. 11 (4): 4351-4359 (2012)

Received January 23, 2012

Accepted June 4, 2012

Published September 25, 2012

DOI http://dx.doi.org/10.4238/2012.September.25.3

\begin{abstract}
Insects use pheromones as a means of chemical communication. Pheromones act on individual receptors and produce specific behavioral or physiological responses that are fundamental to intra- and interspecific recognition. The objective of this study was to evaluate the interspecific differences among the linear hydrocarbon profiles of the cuticles of 3 wasp species of the genus Mischocyttarus. The chemical strategy that permits an interaction among 2 of these species was also examined about their hydrocarbon profiles. The cuticular hydrocarbons present on the abdomen of each individual were extracted with hexane in an ultrasonic bath and analyzed using gas chromatography with a flame ionization detector. The results suggested that the wasp species have distinct chemical signatures as the linear
\end{abstract}


hydrocarbons of their cuticles. However, these signatures are more alike in those with similar morphological and behavioral aspects. These similarities facilitate an interaction of facultative parasitism observed among these species, in which the invaders acquire parts of the chemical signature of the host colony, possibly as a chemical strategy to increase the likelihood that an invader will be accepted by the females of a host colony. Both invader and host have their own chemical signature changed by the first contact between the species.

Key words: Facultative parasitism; Linear alkanes; Gas chromatography

\section{INTRODUCTION}

Social insects exhibit labor division, generation overlap, and cooperative care of offspring (Ross and Matthews, 1991). The completion of multiple tasks in their colonies requires interactions between individuals. Therefore, chemical communication mechanisms via pheromones have been developed during evolution. These compounds act on the individual receiver, producing specific behavioral or physiological responses important in both intra- and interspecific communication (Gullan and Cranston, 2007).

Pheromones have key functions in many aspects of the insect life cycle and are generally divided into 2 types: light and volatile substances secreted by glands and hydrocarbon chains in the cuticle (Howard, 1993). The cuticular hydrocarbons include a wide variety of compounds such as unsaturated hydrocarbons and a series of linear and methyl-branched saturated hydrocarbons (Sledge et al., 2001).

The variation in the chemical composition of the cuticle allows nestmate and non-nestmate recognition (Gamboa, 1996). Insects can also distinguish the larvae of their own colonies (Cotoneschi et al., 2007), workers according to their function (Abdalla et al., 2003; Antonialli Jr. et al., 2008), colonial signatures (Tannure-Nascimento et al., 2007), and even various species (Antonialli Jr. et al., 2007). Furthermore, Espelie and Hermann (1990) have noted that the elements of nest substrates contain hydrocarbons similar or complementary to those that cover the cuticle of adults insect, and they also have important roles in intra- and interspecific recognition.

Polistinae eusocial wasps live in colonies founded by a single female or by more than one female with independent foundations (Ross and Matthews, 1991). Instead of initiating a colony, however, some species can take possession of other colonies owing to the low defensive motivation of the foundresses (Nonacs and Reeve, 1995). Intra- and interspecific facultative parasitism has been described in wasps of the Polistinae family: Vespula, Polistes, and Mischocyttarus (Tinault and Ruano, 1999). Specific cases of intraspecific parasitism have been described in Mischocyttarus flavitarsus (Litte, 1979) and M. mexicanus (Clouse, 1995). In the behavior of social parasitism, beyond exhibiting similar morphological and behavioral aspects to the host, invader species also rub the posterior part of their abdomens against the comb to acquire part of the "scent" of the nest substrate, thereby imitating the chemical signature of the colony and in turn being accepted by the host individuals (Cervo and Dani, 1996; Gamboa, 1996; Lorenzi et al., 2011).

M. consimilis Zikán 1949 is a Neotropical wasp that has been studied recently (Montagna et al., 2009, 2010; Torres et al., 2011). The biological aspects of M. cerberus Richards 
(1940) have been described by Giannotti $(1998,1999)$, Silva and Noda (2000), Filho Costa et al. (2011), and Togni and Giannotti $(2007,2008,2010)$. Females from these species have similar nests and morphologies, differing only in the coloration pattern of the abdomen (Giannotti, 1999; Montagna et al., 2010). The morphological aspects of $M$. latior females differ from those of M. consimilis and M. cerberus (Garcete-Barrett, 2001; Henrique-Simões et al., 2011). We aimed to evaluate the interspecific differences among the linear hydrocarbon profiles of the cuticle of these 3 species of social wasps from the Mischocyttarus genus. Among them, 2 display a facultative parasitic interaction in all areas evaluated in which they co-occur. We also evaluated whether these species use mimicry of the chemical signature as strategy for successful facultative parasitic interactions.

\section{MATERIAL AND METHODS}

\section{Material collection}

To evaluate the differences in cuticular hydrocarbon profiles among wasp species, we collected colonies from various localities in the Mato Grosso do Sul State region (Bodoque-

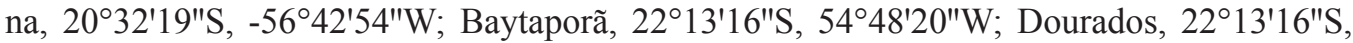

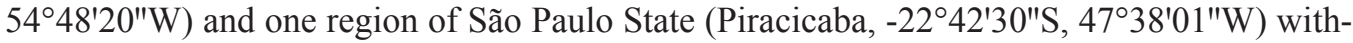
out any interaction between the selected colonies. Three colonies were of $M$. cerberus, 4 of M. consimilis, and 2 of $M$. latior. By evaluating different colonies of different populations, we expected to obtain a most reliable assessment of the profile of hydrocarbons, so we have like a medium profile of each species. The colonies were collected by placing a dark plastic package over the nest and releasing the pedicel. The wasps were anesthetized via chilling on ice, and the abdomens of 4 to 10 individuals were extracted depending on the population of each colony. To evaluate the effects of interactions between M. cerberus and M. consimilis wasps during facultative parasitism, the cuticular hydrocarbon profiles of all of the individuals of 2 colonies of $M$. cerberus invaded by $M$. consimilis were analyzed.

\section{Chemical and statistical analysis}

The cuticular hydrocarbons of 75 abdomens were extracted in $2 \mathrm{~mL}$ hexane (high-performance liquid chromatography grade, Vetec - Química Fina Ltda., Rio de Janeiro, RJ, Brazil) in an ultrasonic bath for $30 \mathrm{~min}$. This process was performed in duplicate. In sequence, the 2 fractions were united and the solvent dried. The dried extract was dissolved in $100 \mu \mathrm{L}$ hexane for analysis using gas chromatography with a flame ionization detector (Focus, GC, Thermo Scientific, San Jose, CA, USA). The gas chromatograph with flame ionization detector was equipped with an OV-5 capillary column (Ohio Valley Specialty Company, Marietta, OH, USA) with a composition of 5\% phenyl-dimethyl-polysiloxane in a fused silica capillary with dimensions of $30 \mathrm{~m}$ in length $\times 0.25 \mathrm{~mm}$ in diameter $\times 0.25-\mu \mathrm{m}$ film thickness. Nitrogen was used as the carrier gas at a constant pressure of 0.8 bar. The analyses were performed in splitless mode with $1-\mu \mathrm{L}$ injection, injector temperature of $250^{\circ} \mathrm{C}$, and detector temperature of $320^{\circ} \mathrm{C}$. The oven was programmed to reach a final temperature of $320^{\circ} \mathrm{C}$, starting from an initial temperature of $50^{\circ} \mathrm{C}$ and rising at a rate of $5^{\circ} \mathrm{C} / \mathrm{min}$ to $85^{\circ} \mathrm{C}$, then rising at a rate of $8^{\circ} \mathrm{C} / \mathrm{min}$ to $300^{\circ} \mathrm{C}$, which was held for $15 \mathrm{~min}$, and then raised to $320^{\circ} \mathrm{C}$ at a rate of $10^{\circ} \mathrm{C} / \mathrm{min}$ and held for $35 \mathrm{~min}$. 
The chromatograms were registered using the ChromQuest 5.0 program and analyzed with the Workstation Chrom Data Review program. The chemical compounds were identified based on linear hydrocarbon standards of $\mathrm{C}_{7}$ to $\mathrm{C}_{40}(4 \mu \mathrm{g} / \mathrm{mL}$ in hexane) through comparison with retention times. The concentration of each compound was calculated using relative area, in percentage, referring to the peak areas of alkanes $\mathrm{C}_{7}$ to $\mathrm{C}_{40}$.

The differentiation analysis of the species was completed using the peak areas of the corresponding $\mathrm{C}_{15}$ to $\mathrm{C}_{30}$ hydrocarbons, which are common to all of the species. The differentiation was carried out using the stepwise discriminate function analysis of Statistica 7 and indicated by selecting a set of variables that best differentiate (case has difference) the groups analyzed (Quinn and Keough, 2002). In this analysis, the Wilk's lambda statistic is used as a measurement of the difference between the groups, in which values close to 0 indicate that the groups do not overlap, whereas values close to 1 indicate high overlap among groups and a lack of significant difference.

\section{RESULTS AND DISCUSSION}

Figure 1 shows the discriminate analysis of the peak areas of linear alkanes identified in the cuticular extract of worker abdomens of $M$. consimilis, M. cerberus, and M. latior. The dispersion graphic shows that the chemical compositions of the hydrocarbon profiles of the 3 species are distinct. In fact, the values of Wilk's lambda of 0.017 and F of 23.064 demonstrate significant differences between the hydrocarbon profiles $(\mathrm{P}<0.000)$, with canonical root 1 explaining $70 \%$ and, along with root $2,100 \%$ of the data. These results reinforce the importance of hydrocarbon profiles in the recognition of signals and species distinction, corroborating the findings of Howard and Blomquist (2005).

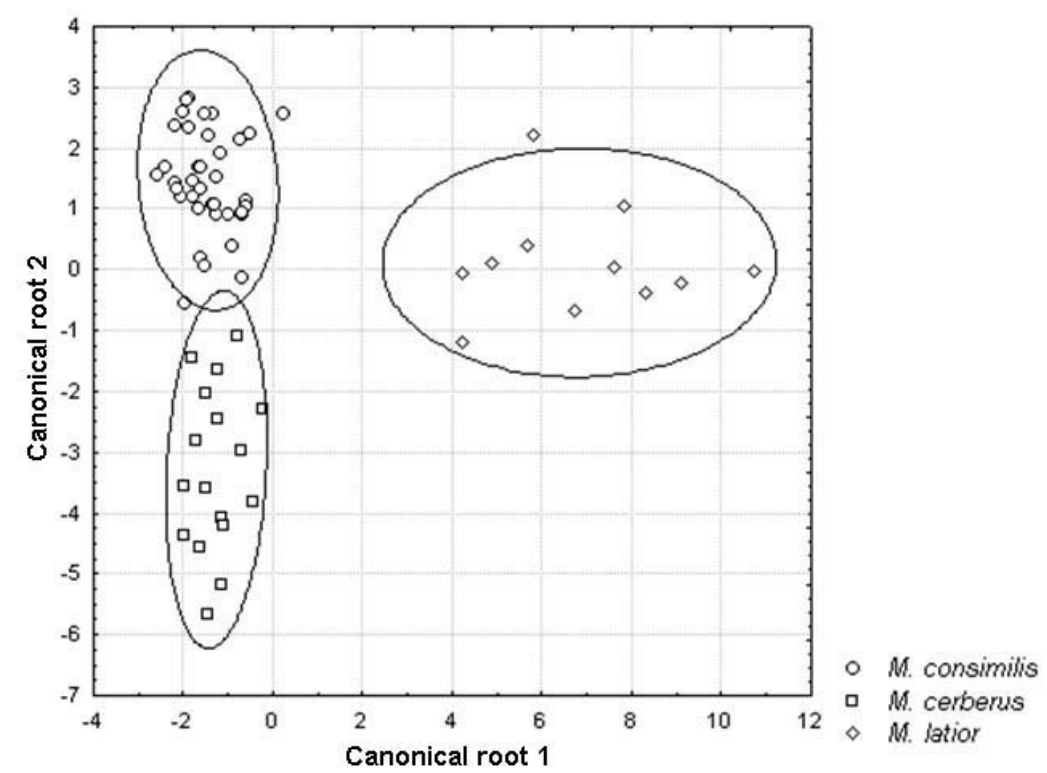

Figure 1. Dispersion diagram of discriminate analysis results showing the two canonical roots of differentiation of 3 species of wasps of the genus Mischocyttarus based on the profiles of cuticular hydrocarbons. 
Table 1 lists the linear alkanes present or absent in the hydrocarbon profiles of the 3 wasp species, given that alkanes $\mathrm{C}_{35}$ to $\mathrm{C}_{40}$ were absent in all of the species studied. Hydrocarbons $\mathrm{C}_{15}$ to $\mathrm{C}_{30}$ were the most important in distinguishing the species because they are present in each but in different concentrations (see Table 1). The results show that the profile of M. latior is more distinct than that of the other 2 species (see Figure 1), mainly owing to the presence of a large concentration of $n$-heptacosane $\left(\mathrm{C}_{27}\right)$. Greater overlap was found between $M$. consimilis and $M$. cerberus. These species also share similar morphological and behavioral characteristics (Giannotti, 1998, 1999; Silva and Noda, 2000; Togni and Giannotti, 2007, 2008, 2010; Montagna et al., 2009, 2010; Filho Costa et al., 2011; Torres et al., 2011). $N$-nonacosane $\left(\mathrm{C}_{29}\right)$ and $n$ triacontane $\left(\mathrm{C}_{30}\right)$, in the sequence, identified the M. consimilis and M. cerberus species because these compounds are found in high concentrations in these species (see Table 1).

Table 1. Identification of hydrocarbons present or absent in the hydrocarbon profiles and the statistical values of the discriminate analysis of the peaks corresponding to the most significant alkanes for species differentiation followed by average concentration values in percentage of area.

\begin{tabular}{|c|c|c|c|c|c|c|c|c|c|c|c|}
\hline \multirow[t]{2}{*}{$\mathrm{HC}$} & \multirow[t]{2}{*}{ Nomenclature } & \multicolumn{3}{|c|}{ Presence or absence } & \multirow[t]{2}{*}{$\begin{array}{l}\text { Wilk's } \\
\text { lambda }\end{array}$} & \multirow[t]{2}{*}{$P$} & \multicolumn{2}{|c|}{$\begin{array}{l}\text { Canonical } \\
\text { coefficients }\end{array}$} & \multicolumn{3}{|c|}{$\%$ Relative area } \\
\hline & & M. consimilis & M. cerberus & M. latior & & & Root 1 & Root 2 & M. consimilis & M. cerberus & M. latior \\
\hline $\mathrm{C}_{7}$ & n-heptane & 1 & 1 & 0 & - & - & - & - & - & - & - \\
\hline $\mathrm{C}_{8}$ & n-octane & 1 & 1 & 0 & - & - & - & - & - & - & - \\
\hline $\mathrm{C}_{9}$ & n-nonane & 1 & 1 & 1 & - & - & - & - & - & - & - \\
\hline $\mathrm{C}_{10}$ & n-decane & 0 & 1 & 0 & - & - & - & - & - & - & - \\
\hline $\mathrm{C}_{11}$ & n-undecane & 1 & 1 & 1 & - & - & - & - & - & - & - \\
\hline $\mathrm{C}_{12}$ & n-dodecane & 0 & 0 & 1 & - & - & - & - & - & - & - \\
\hline$C_{13}$ & n-tridecane & 0 & 1 & 0 & - & - & - & - & - & - & - \\
\hline $\mathrm{C}_{14}$ & n-tetradecane & 1 & 1 & 1 & - & - & - & - & - & - & - \\
\hline $\mathrm{C}_{15}$ & $\mathrm{n}$-pentadecane & 1 & 1 & 1 & 0.03 & $<0.00$ & 0.21 & -1.53 & $0.11 \pm 0.07$ & $0.44 \pm 0.46$ & $0.06 \pm 0.02$ \\
\hline $\mathrm{C}_{16}$ & n-hexadecane & 1 & 1 & 1 & 0.02 & $\mathrm{~ns}$ & & & & & \\
\hline$C_{17}^{10}$ & n-heptadecane & 1 & 1 & 1 & 0.02 & $<0.02$ & -0.66 & 1.03 & $0.48 \pm 0.24$ & $0.83 \pm 0.92$ & $0.16 \pm 0.04$ \\
\hline $\mathrm{C}_{18}$ & n-octadecane & 1 & 1 & 1 & 0.02 & ns & & & & & \\
\hline$C_{19}$ & n-nonadecane & 1 & 1 & 1 & 0.02 & $\mathrm{~ns}$ & & & & & \\
\hline $\mathrm{C}_{20}$ & n-eicosane & 1 & 1 & 1 & & & & & & & \\
\hline $\mathrm{C}_{21}^{20}$ & n-heneicosane & 1 & 1 & 1 & 0.02 & $<0.05$ & -0.17 & -0.58 & $6.24 \pm 6.72$ & $5.55 \pm 11.71$ & $0.06 \pm 0.02$ \\
\hline $\mathrm{C}_{22}^{21}$ & n-docosane & 1 & 1 & 1 & & & & & & & \\
\hline $\mathrm{C}_{23}^{22}$ & n-tricosane & 1 & 1 & 1 & 0.02 & ns & & & & & \\
\hline $\mathrm{C}_{24}$ & n-tetracosane & 1 & 1 & 1 & 0.02 & ns & & & & & \\
\hline $\mathrm{C}_{25}$ & n-pentacosane & 1 & 1 & 1 & 0.02 & ns & & & & & \\
\hline $\mathrm{C}_{26}$ & n-hexacosane & 1 & 1 & 1 & 0.02 & $<0.01$ & 1.00 & -1.40 & $0.71 \pm 1.18$ & $3.37 \pm 3.79$ & $3.48 \pm 0.89$ \\
\hline $\mathrm{C}_{27}^{26}$ & n-heptacosane & 1 & 1 & 1 & 0.03 & $<0.00$ & 1.10 & 0.51 & $17.59 \pm 11.70$ & $12.41 \pm 9.40$ & $73.54 \pm 11.35$ \\
\hline $\mathrm{C}_{28}^{27}$ & n-octacosane & 1 & 1 & 1 & 0.02 & $\mathrm{~ns}$ & & & & & \\
\hline $\mathrm{C}_{29}^{28}$ & n-nonacosane & 1 & 1 & 1 & 0.02 & $<0.02$ & -0.56 & 0.28 & $46.32 \pm 22.00$ & $39.13 \pm 18.45$ & $11.67 \pm 8.01$ \\
\hline $\mathrm{C}_{30}$ & n-triacontane & 1 & 1 & 1 & 0.02 & $<0.02$ & 0.36 & -0.58 & $1.74 \pm 1.17$ & $13.42 \pm 6.78$ & $0.66 \pm 0.27$ \\
\hline $\mathrm{C}_{31}$ & $\mathrm{n}$-hentriacontane & 1 & 1 & 1 & - & - & - & - & - & - & - \\
\hline $\mathrm{C}_{32}$ & n-dotriacontane & 1 & 1 & 1 & - & - & - & - & - & - & - \\
\hline $\mathrm{C}_{33}$ & n-tritriacontane & 1 & 1 & 0 & - & - & - & - & - & - & - \\
\hline $\mathrm{C}_{34}$ & n-tetratriacontane & 1 & 1 & 0 & - & - & - & - & - & - & - \\
\hline
\end{tabular}

$\mathrm{HC}=$ hydrocarbons; ns = non-significant.

Dapporto et al. (2006) have also found high concentrations of linear alkanes with the carbon chains of $\mathrm{C}_{23}$ to $\mathrm{C}_{33}$ in Ropalidia opifex. In Polistes satan, the linear alkanes of $n$-heptacosane $\left(\mathrm{C}_{27}\right), n$-octacosane $\left(\mathrm{C}_{28}\right)$, and $n$-tritriacontane $\left(\mathrm{C}_{33}\right)$ are more significant than methyl-branched alkanes in the separation of colonies (Tannure-Nascimento et al., 2007).

The results demonstrate that $M$. consimilis and M. cerberus have distinct hydrocarbon profiles (Figure 2), that a clear separation of the groups is present, and that the significant 
differences among the linear hydrocarbon profiles of 2 of the species were detected in the canonical discrimination analysis (Wilk's lambda $=0.036 ; \mathrm{F}=8.792 ; \mathrm{P}<0.000$ ). This separation was determined by the linear alkanes $\mathrm{C}_{15}, \mathrm{C}_{19}, \mathrm{C}_{23}, \mathrm{C}_{26}, \mathrm{C}_{27}, \mathrm{C}_{29}$, and $\mathrm{C}_{30}$ (Table 2), which were significant to the 2 canonical roots. $N$-heptacosane $\left(\mathrm{C}_{27}\right)$ occurs in higher concentrations in $M$. consimilis, and $n$-triacontane $\left(\mathrm{C}_{30}\right)$ occurs in higher concentrations in M. cerberus (see Table 2 ).

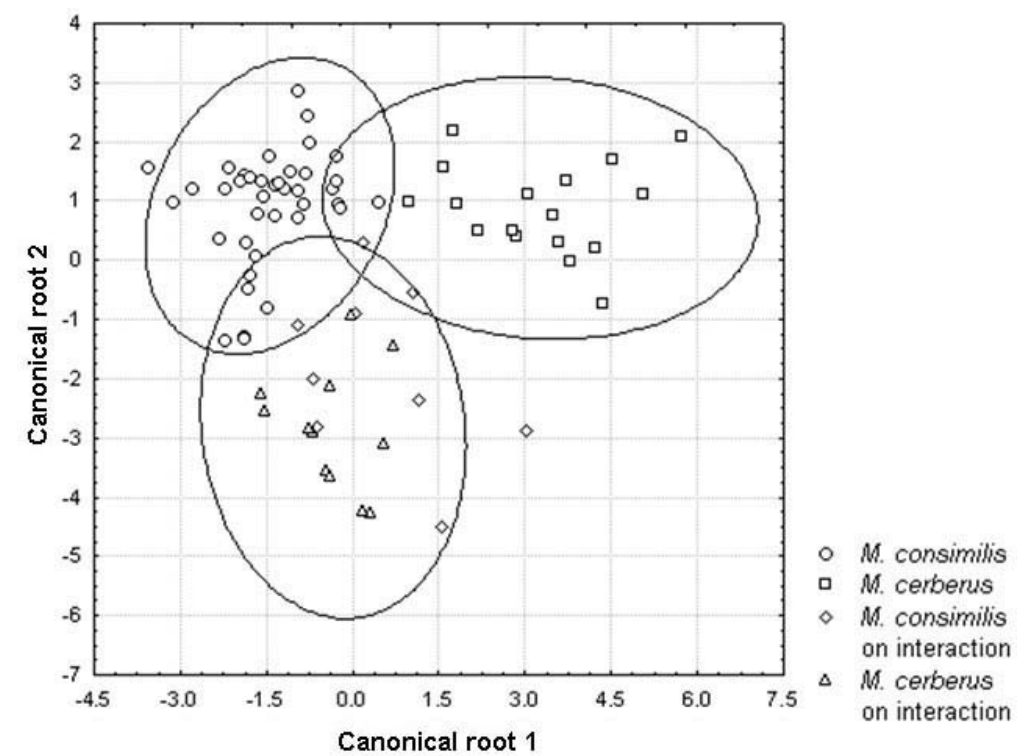

Figure 2. Dispersion diagram of discriminate analysis results showing the 2 canonical roots of differentiation based on the hydrocarbon profiles of Mischocyttarus consimilis and M. cerberus in colonies with and without interaction.

Table 2. Statistical values of the discriminate analysis of the most significant alkanes responsible for the distinction of Mischocyttarus consimilis and M. cerberus and of the individuals interacting parasitically, with average values of percentage area.

\begin{tabular}{|c|c|c|c|c|c|c|c|c|}
\hline \multirow[t]{2}{*}{$\mathrm{HC}$} & \multirow[t]{2}{*}{ Nomenclature } & \multirow[t]{2}{*}{ Wilk's lambda } & \multirow[t]{2}{*}{$\mathrm{P}$} & \multicolumn{2}{|c|}{ Canonical coefficients } & \multicolumn{3}{|c|}{$\%$ Relative area } \\
\hline & & & & Root 1 & Root 2 & M. consimilis & M. cerberus & On interaction \\
\hline $\mathrm{C}_{15}$ & n-pentadecane & 0.07 & $<0.00$ & 1.36 & -0.09 & $0.11 \pm 0.07$ & $0.46 \pm 0.04$ & $0.25 \pm 0.18$ \\
\hline $\mathrm{C}_{16}^{13}$ & n-hexadecane & 0.04 & ns & & & & & \\
\hline $\mathrm{C}_{17}^{16}$ & n-heptadecane & 0.03 & $\mathrm{~ns}$ & & & & & \\
\hline $\mathrm{C}_{18}^{17}$ & n-octadecane & 0.04 & ns & & & & & \\
\hline $\mathrm{C}_{19}^{10}$ & n-nonadecane & 0.04 & $<0.02$ & 0.08 & -0.49 & $0.31 \pm 0.25$ & $0.25 \pm 0.14$ & $2.17 \pm 2.64$ \\
\hline $\mathrm{C}_{21}^{19}$ & n-heneicosane & 0.04 & ns & & & & & \\
\hline $\mathrm{C}_{23}^{21}$ & n-tricosane & 0.06 & $<0.00$ & -0.31 & -0.52 & $16.59 \pm 18.88$ & $8.08 \pm 15.29$ & $19.96 \pm 24.46$ \\
\hline $\mathrm{C}_{24}^{23}$ & n-tetracosane & 0.04 & ns & & & & & \\
\hline $\mathrm{C}_{25}^{24}$ & n-pentacosane & 0.04 & $\mathrm{~ns}$ & & & & & \\
\hline $\mathrm{C}_{26}^{23}$ & n-hexacosane & 0.05 & $<0.00$ & 2.96 & -0.38 & $0.73 \pm 1.17$ & $3.37 \pm 3.79$ & $0.89 \pm 1.36$ \\
\hline $\mathrm{C}_{27}^{20}$ & n-heptacosane & 0.04 & $<0.01$ & -0.24 & 0.74 & $18.23 \pm 13.02$ & $12.41 \pm 9.40$ & $6.28 \pm 3.00$ \\
\hline $\mathrm{C}_{28}^{27}$ & n-octacosane & 0.04 & ns & & & & & \\
\hline $\mathrm{C}_{29}^{28}$ & n-nonacosane & 0.05 & $<0.00$ & -0.41 & -0.69 & $45.10 \pm 22.15$ & $39.13 \pm 18.45$ & $54.96 \pm 22.98$ \\
\hline $\mathrm{C}_{30}^{29}$ & n-triacontane & 0.06 & $<0.00$ & 0.88 & 0.84 & $1.68 \pm 1.16$ & $13.42 \pm 6.77$ & $2.14 \pm 1.08$ \\
\hline
\end{tabular}


Conversely, the chemical signatures of $M$. consimilis and $M$. cerberus are similar in colonies under interaction (see Figure 2). A greater overlap of statistical data of these interacting colonies was found compared to those of the 2 species without any interaction. A plausible conclusion is that the parasitic species can acquire part of the chemical signature of host colonies after first contact with their colonies, especially through contact with the substrate of their nests (Lorenzi and Cervo, 1992; Cervo and Lorenzi, 1996). Our results corroborate the conclusions of Cervo and Lorenzi (1996), who have observed that when females of Polistes biglumis invaded a host colony, they often vibrate their abdomens against the nest substrate, which suggests that the usurper species may attempt to acquire an odor similar to that of the host species.

The chemical signature of the host species changed after contact with the invader (see Figure 2), suggesting that the signatures of both species undergo modification through contact between individuals and nest structure.

The similarity of the chemical signatures of M. cerberus and M. consimilis in interactive colonies is defined by high concentrations of $n$-nonacosane $\left(\mathrm{C}_{29}\right)$ in the cuticles of both species (see Table 2). After the first contact between the 2 species, the concentration of $n$-nonacosane is altered. A similar phenomenon occurs in P. biglumis, in which the concentration of branched hydrocarbons in the nest material is altered owing to the overlap of the nest substrate, which is first realized by the queen of host colony and then by the usurper when this rubs its abdomen against the nest, intensifying the quantity of hydrocarbons present in the nest substrate (Lorenzi, 2011). Lorenzi and Cervo (1992) and Cervo and Lorenzi (1996) suggest that the female parasites acquire the profile of the host keeping contact with the material of the nest that seems to have similar elements to those present in the cuticle of individuals of the colony, which was noticed by Espelie and Hermann (1988, 1990), Espelie et al. (1990) and Singer et al. (1992). Due to this, Shellman and Gamboa (1982), Pfennig et al. (1983a,b), and Gamboa et al. (1986a,b) found that contact with the nest substrate is important in Polistes species for the nestmates recognition via chemical signals.

Our results suggest that the 3 species of Mischocyttarus wasps studied have distinct chemical signatures, at least in terms of the linear hydrocarbons of their cuticles. However, these signatures are more alike in species with similar behavioral and morphological aspects. These similarities facilitate to occur a facultative parasitism interaction among the $M$. consimilis and $M$. cerberus species, in which the invader acquires part of the chemical signature of the host colony, which changes the chemical signature of both species after first contact, thus suggesting a chemical strategy to increase the acceptance of the invader by females of the host colony.

\section{ACKNOWLEDGMENTS}

Research supported by FUNDECT. We thank Universidade Estadual de Mato Grosso do Sul (UEMS) for technical support, and Conselho Nacional de Desenvolvimento Científico e Tecnológico (CNPq) for the productivity scholarship of W.F. Antonialli-Junior.

\section{REFERENCES}

Abdalla FC, Jones GR, Morgan ED and da Cruz-Landim C (2003). Comparative study of the cuticular hydrocarbon
composition of Melipona bicolor Lepeletier, 1836 (Hymenoptera, Meliponini) workers and queens. Genet. Mol. Res.
2: 191-199.
Antonialli WF Jr, Lima SM, Andrade LH and Suarez YR (2007). Comparative study of the cuticular hydrocarbon in

Genetics and Molecular Research 11 (4): 4351-4359 (2012)

CFUNPEC-RP www.funpecrp.com.br 
queens, workers and males of Ectatomma vizottoi (Hymenoptera, Formicidae) by Fourier transform-infrared photoacoustic spectroscopy. Genet. Mol. Res. 6: 492-499.

Antonialli WF Jr, Suarez YR, Izida T, Andrade LH, et al. (2008). Intra- and interspecific variation of cuticular hydrocarbon composition in two Ectatomma species (Hymenoptera: Formicidae) based on Fourier transform infrared photoacoustic spectroscopy. Genet. Mol. Res. 7: 559-566.

Cervo R and Dani FR (1996). Social Parasitism and its Evolution in Polistes. In: Natural History and Evolution of PaperWasps (Turillazzi S and West-Eberhard MJ, eds.). Oxford University Press, New York, 98-112.

Cervo R and Lorenzi MC (1996). Behaviour in usurpers and late joiners of Polistes biglumis bimaculatus (Hymenoptera: Vespidae). Insect Soc. 266: 255-266.

Clouse RM (1995). Nest Usurpation and Intercolonial Cannibalism in Mischocyttarus mexicanus (Hymenoptera: Vespidae). J. Kansas Entomol. Soc. 68: 67-73.

Cotoneschi C, Dani FR, Cervo R, Sledge MF, et al. (2007). Polistes dominulus (Hymenoptera: Vespidae) larvae possess their own chemical signatures. J. Insect Physiol. 53: 954-963.

Dapporto L, Fondelli L and Turillazi S (2006). Nestmate recognition and identification of cuticular hydrocarbons composition in the swarm founding paper wasp Ropalidia opifex. Biochem. Systemat. Ecol. 34: 617-625.

Espelie KE and Hermann HR (1988). Congruent cuticular hydrocarbons: biochemical convergence of a social wasp, an ant and a host plant. Biochem. Systemat. Ecol. 16: 505-508.

Espelie KE and Hermann HR (1990). Surface lipids of the social wasp Polistes annularis (L.) and its nest and nest pedicel. J. Chem. Ecol. 16: 1841-1852.

Espelie KE, Butz VM and Dietz A (1990). Dexydecanoate: a major component of the tergite glands of honeybee queens (Apis mellifera L.). J. Apicult. Res. 29: 15-19.

Filho Costa VC, Shima SN, Desuó IC and Murakami ASN (2011). The effects of the social hierarchy destabilization on the foraging activity of eusocial wasp Mischocyttarus cerberus styx Richards, 1940 (Hymenoptera: Vespidae: Polistinae). Psyche 2011: 1-8.

Gamboa GJ (1996). Kin Recognition in Social Wasps. In: Natural History and Evolution of Paper-Wasps (Turillazzi S and West-Eberhard MJ, eds.). Oxford University Press, Oxford, 161-177.

Gamboa GJ, Reeve HK, Ferguson ID and Wacker TL (1986a). Nestmate recognition in social wasps: the origin and acquisition of recognition odours. Anim. Behav. 34: 685-695.

Gamboa GJ, Reeve HK and Pfennig DW (1986b). The evolution and ontogeny of Nestmate recognition in social wasps. A Rev. Entomol. 31: 431-454.

Garcete-Barrett BR (2001). Seis nuevos registros de avispas sociales para el Paraguay (Hymenoptera: Vespidae: Polistinae). Bol. Mus. Nac. Parag. 13: 46-49.

Giannotti E (1998). The colony cycle of the social wasp, Mischocyttarus cerberus styx Richards, 1940 (Hymenoptera, Vespidae). Rev. Bras. Entomol. 41: 217-224.

Giannotti E (1999). Social organization of the eusocial wasp Mischocyttarus cerberus styx (Hymenoptera, Vespidae). Sociobiology 33: 325-338.

Gullan PJ and Cranston PS (2007). Os Insetos: Um Resumo de Entomologia. $3^{\mathrm{a}}$ ed. Roca, São Paulo.

Henrique-Simões M, Cuozzo MD and Frieiro-Costa FA (2011). Social wasps of Unilavras/Boqueirão biological Reserve, Ingaí, state of Minas Gerais, Brazil. Check List: J. Spec. Lists Distrib. 7: 656-667.

Howard RW (1993). Cuticular Hydrocarbon and Chemical Communication. In: Insect Lipids: Chemistry, Biochemistry and Biology (Stanley-Samuelson DW and Nelson DR, eds.). University of Nebraska Press, Lincoln, 179-226.

Howard RW and Blomquist GJ (2005). Ecological, behavioral, and biochemical aspects of insect hydrocarbons. Annu. Rev. Entomol. 50: 371-393.

Litte M (1979). Mischocyttarus flavitarsis in Arizona: social and nesting biology of a polistine wasp. Ethology 50: 282-312.

Lorenzi MC and Cervo R (1992). Behaviour of Polistes biglumis bimaculatus (Hymenoptera: Vespidae) Foundresses on Alien Conspecific Nests. In: Biology and Evolution of Social Insects (Billen J, ed.). Leuven University Press, Leuven, 273-279.

Lorenzi MC, Cervo R and Bagnères AG (2011). Facultative social parasites mark host nests with branched hydrocarbons. Anim. Behav. 82: 1143-1149.

Montagna TS, Torres VO, Dutra CC, Súarez YD, et al. (2009). Study of the foraging activity of Mischocyttarus consimilis (Hymenoptera: Vespidae). Sociobiology 53: 131-140.

Montagna TS, Torres VO, Fernandes WD and Antonialli WF Jr (2010). Nest architecture, colony productivity, and duration of immature stages in a social wasp, Mischocyttarus consimilis. J. Insect Sci. 10: 191.

Nonacs P and Reeve HK (1995). The ecology of cooperation in wasps: causes and consequences of alternative reproductive decisions. Ecology 76: 953-967.

Pfennig DW, Gamboa GJ, Reeve HK, Reeve JS, et al. (1983a). The mechanism of nestmate discrimination in social wasps

Genetics and Molecular Research 11 (4): 4351-4359 (2012)

CFUNPEC-RP www.funpecrp.com.br 
(Polistes, Hymenoptera: Vespidae). Behav. Ecol. Sociob. 13: 299-305.

Pfennig DW, Reeve HK and Shellman JS (1983b). Learned component of nestmate discrimination in workers of a social wasp, Polistes fuscatus (Hymenoptera: Vespidae). Anim. Behav. 31: 412-416.

Quinn GP and Keough MJ (2002). Experimental Design and Data Analysis for Biologists. Cambridge University Press, Cambridge.

Ross RW and Matthews RW (1991). The Social Biology of Waps. Department of Entomology: University of Georgia, Georgia.

Shellman JS and Gamboa GJ (1982). Nestmate discrimination in social wasps: the role of exposure to nest and nestmates (Polistes fuscatus, Hymenoptera: Vespidae). Behav. Ecol. Sociob. 11: 51-53.

Silva ER and Noda SCM (2000). Aspectos da atividade forrageadora de Mischocyttarus cerberus styx Richards, 1940 (Hymenoptera, Vespidae): duração das viagens, especialização individual e ritmos diários e sazonal. Rev. Bras. Zoociências 2: 7-20.

Singer TL, Camann MA and Espelie KE (1992). Discriminant analysis of cuticular hydrocarbons of social wasp Polistes exclamans Viereck and surface hydrocarbons of its nest paper and pedicel. J. Chem. Ecol. 18: 785-797.

Sledge MF, Boscaro F and Turillazi S (2001). Cuticular hydrocarbons and reproductive status in the social wasp Polistes dominulus. Behav. Ecol. Sociobiol. 49: 401-409.

Tannure-Nascimento IC, Nascimento FS, Turatti IC, Lopes NP, et al. (2007). Colony membership is reflected by variations in cuticular hydrocarbon profile in a Neotropical paper wasp, Polistes satan (Hymenoptera, Vespidae). Genet. Mol. Res. 6: 390-396.

Tinault A and Ruano F (1999). Parasitismo social. Boletin SEA 26: 727-740.

Togni OC and Giannotti E (2007). Nest defense behavior against the attack of ants in colonies of pre-emergent Mischocyttarus cerberus (Hymenoptera: Vespidae). Sociobiology 50: 675-694.

Togni OC and Giannotti E (2008). Nest defense behavior against ant attacks in post-emergent colonies of wasp Mischocyttarus cerberus (Hymenoptera: Vespidae). Acta Ethol. 11: 43-54.

Togni OC and Giannotti E (2010). Colony defense behavior of the primitively eusocial wasp, Mischocyttarus cerberus is related to age. J. Insect Sci. 10: 136.

Torres VO, Montagna TS, Fernandes WD and Antonialli WF Jr (2011). Colony cycle of the social wasp Mischocyttarus consimillis Zikán (Hymenoptera, Vespidae). Rev. Bras. Ent. 55: 247-252. 